\title{
ІНЖЕНЕРНІ НАУКИ
}

УДК 620.92:621.383.51

https://doi.org/10.35546/kntu2078-4481.2021.3.1

О.В. АНДРОНОВА

Херсонський національний технічний університет ORCID: 0000-0001-9597-8068

B.В. КУРАК

Херсонський національний технічний університет ORCID: 0000-0002-4303-5671

Н.Л. ДОН

Херсонський національний технічний університет ORCID: 0000-0001-9503-5326

\section{МОДЕЛЮВАННЯ РОБОТИ ФОТОЕЛЕКТРИЧНИХ ПАНЕЛЕЙ 3 ВИКОРИСТАННЯМ СЕРЕДОВИЩА МАТLAВ/SIMULINK}

Моделювання параметрів фотоелектричних панелей надає можливість в найкоротмі терміни спрогнозувати показники роботи фотоелектричної станції в розрізі конкретної доби, місяця та протягом року для будь-якої місчевості та способу розташування сонячних модулів. Одним з потужних засобів комп'ютерної математики, щчо останнім часом набуває широкого використання для моделювання різноманітних технічних систем, є середовище MATLAB, яке завдяки вбудованому пакету Simulink дозволяє здійснювати візуально-орієнтоване блочне імітаційне моделювання динамічних систем, зокрема, різних пристроїв функціональної електроніки, сонячних елементів та фотоелектричних модулів.

В даній роботі запропоновано підхід до моделювання роботи реальних фотоелектричних панелей в середовищі MATLAB/Simulink при використанні в якості вхідних даних до блоку Solar Cell інформачії з технічної документації до панелей.

Представлено методику визначення вхідних параметрів блоку Solar Cell, які не зазначені в технічній документації сонячної панелі, щзо передбачає аналіз світлової вольт-амперної характеристики панелі для стандартних умов тестування у наближенні однодіодної еквівалентної схеми фотоелектричного перетворювача. Апробацію даної методики здійснено на прикладі панелей JAP6(BK) 60-250/3BB, AS-6P30-270W ma LG290N1C від провідних світових виробників.

У середовищі MATLAB/Simulink створено візуально-орієнтовану блочну схему з побудови світлових характеристик фотоелектричних панелей, щзо базується на використанні блоку Solar Cell, проведено моделювання характеристик панелей JAP6(BK) 60-250/3BB, AS-6P30-270W ma LG290N1C, визначено їх основні параметри в стандартних умовах тестування. Порівняння параметрів панелей, визначених з аналізу змодельованих світлових характеристик, з даними, наведеними у технічній документації, показало, щьо розбіжність між результатами моделювання та параметрами з технічної документації $\epsilon$ меншою за допустиме $y$ виробництві відхилення y 3\% для всіх панелей, щзо досліджувались. Це свідчить про прийнятність запропонованого підходу до моделювання роботи реальних фотоелектричних панелей у середовищі MATLAB/Simulink.

Ключові слова: фотоелектрична панель, фотоелектричний перетворювач, однодіодна еквівалентна схема, світлова вольт-амперна характеристика, моделювання, MATLAB/Simulink.

Е.В. АНДРОНОВА

Херсонский национальный технический университет ORCID: 0000-0001-9597-8068

B.В. КУРАК

Херсонский национальный технический университет ORCID: 0000-0002-4303-5671

Н.Л. ДОН

Херсонский национальный технический университет ORCID: 0000-0001-9503-5326

\section{МОДЕЛИРОВАНИЕ РАБОТЫ ФОТОЭЛЕКТРИЧЕСКИХ ПАНЕЛЕЙ С ИСПОЛЬЗОВАНИЕМ СРЕДЫ МАTLAB/SIMULINK}

Моделирование параметров фотоэлектрических панелей дает возможность в кратчайшие сроки спрогнозировать показатели работы фотоэлектрической станиии в разрезе конкретных суток, 
месяияа и на протяжении года для какой-либо местности и способа расположения солнечных модулей. Одним из мощцных средств компьютерной математики, которое в последнее время широко используется для моделирования различных технических систем, является среда МАТLАВ, которая благодаря встроенному пакету Simulink позволяет осуществлять визуально-ориентированное блочное имитационное моделирование динамических систем, в частности, различных устройств функииональной электроники, солнечных элементов и фотоэлектрических модулей.

В данной работе предложен подход к моделированию работь реальных фотоэлектрических панелей в среде MATLAB/Simulink при использовании в качестве входных данных в блоке Solar Cell информации из технической документаџии панели.

Представлена методика определения входных параметров блока Solar Cell, которые не указаны 8 технической документации солнечной панели, предусматривающая анализ световой вольтамперной характеристики панели для стандартных условий тестирования в приближении однодиодной эквивалентной схемы фотоэлектрического преобразователя. Апробация данной методики осуществлена на примере панелей JAP6(BK) 60-250/3BB, AS-6P30-270W и LG290N1C от ведущих мировых производителей.

В среде MATLAB/Simulink создана визуально-ориентированная блочная схема для построения световых характеристик фотоэлектрических панелей, базирующаяся на использовании блока Solar Cell, проведено моделирование характеристик панелей JАР6(BK) 60-250/3BB, AS-6P30-270W и LG290N1C, определены их основные параметры в стандартных условиях тестирования. Сравнение параметров панелей, определенных из анализа смоделированных световых характеристик, $c$ данными, представленными в технической документации, показало, что отклонение результатов моделирования от параметров из технической документации составляет меньше допустимых в условиях производства 3\% для всех исследованных панелей. Это свидетельствует о приемлемости предложенного подхода $к$ моделированию работы реальных фотоэлектрических панелей в среде MATLAB/Simulink.

Ключевые слова: фотоэлектрическая панель, фотоэлектрический преобразователь, однодиодная эквивалентная схема, световая вольтамперная характеристика, моделирование, MATLAB/Simulink.

E.V. ANDRONOVA

Kherson National Technical University ORCID: 0000-0001-9597-8068

V.V. KURAK

Kherson National Technical University ORCID: 0000-0002-4303-5671

N.L. DON

Kherson National Technical University ORCID: 0000-0001-9503-5326

\section{SIMULATION OF PHOTOVOLTAIC PANELS OPERATION USING MATLAB/SIMULINK}

Modeling of the photovoltaic panels' parameters makes it possible to predict in the shortest time the performance of a photovoltaic station in the context of specific days, months and along the year for any area and the method of solar panels arranging. One of powerful tools of computer mathematics, which recently has been widely used to simulate various technical systems, is the MATLAB environment. Due to the built-in Simulink package, MATLAB allows to realize visual-oriented block simulation of dynamic systems, in particular, various devices of functional electronics, solar cells and photovoltaic modules.

This paper proposes an approach to modeling the operation of real photovoltaic panels in the MATLAB/Simulink environment using information from the panel technical documentation as input data for the Solar Cell block.

The method for determining the input parameters of the Solar Cell block, which are not specified in the technical documentation of the solar panel, is presented. This method is based on the analysis of the light current-voltage characteristic of the panel for standard test conditions in the approximation of a single-diode equivalent circuit of a photovoltaic cell. Proposed method was tested on the example of JAP6(BK) 60-250/3BB, AS-6P30-270W and LG290N1C panels from the world's leading manufacturers.

A visual-oriented model based on Solar Cell block was created in the MATLAB/Simulink environment to build the light characteristics of photovoltaic panels. The light characteristics of the JAP6(BK) 60-250/3BB, AS-6P30-270W and LG290N1C panels were simulated using created model, and main parameters of the panels under standard test conditions were calculated. Comparison of the panels parameters determined from the simulated light characteristics with the data presented in the technical documentation showed that for all panels the deviation of the simulation results from the documentation parameters is less than permissible 3\%. This indicates the acceptability of the proposed approach to modeling the operation of real photovoltaic panels in the 


\section{MATLAB / Simulink environment.}

Keywords: photovoltaic panel, photovoltaic cell, single-diode equivalent circuit, light current-voltage characteristic, simulation, MATLAB/Simulink.

\section{Постановка проблеми}

Вирішальний вплив умов експлуатації на енергетичні параметри фотоелектричних панелей потребує організації досліджень їх електричних характеристик в кліматичних умовах конкретного місця розташування сонячної електростанції. Експериментальний підхід до вирішення цієї задачі пов'язаний $з$ отриманням масиву даних щодо ефективності перетворення сонячної енергії панеллю в кліматичних умовах заданої місцевості і реалізується протягом тривалого часу для забезпечення репрезентативності результатів.

Альтернативою експериментальному підходу є моделювання параметрів фотоелектричних панелей з використанням кліматичних даних місцевості, отриманих на основі результатів багаторічних спостережень [1]. Головною перевагою такого підходу $\epsilon$ можливість в найкоротші терміни спрогнозувати показники роботи фотоелектричної станції в розрізі конкретної доби, місяця та протягом року для будь-якої місцевості й способу розташування панелей.

\section{Аналіз останніх досліджень і публікацій}

Моделі фотоелектричних панелей базуються на рівнянні світлової вольт-амперної характеристики (BAX), що може бути записана у відповідності до однодіодної та дводіодної еквівалентної схеми фотоелектричного перетворювача (ФЕП) [2].

Відповідно до однодіодної схеми ФЕП світлова ВАХ як залежність струму Івід напруги $U$ представляється у наступному вигляді [3]:

$$
I=I_{L}-I_{S} \cdot\left[e^{\frac{q_{e}\left(U+I R_{S}\right)}{A k T}}-1\right]-\frac{U+I R_{S}}{R_{p}},
$$

де $\quad I_{L}-$ величина фотоструму;

$I_{S}$ - струм насичення діоду;

$A$ - коефіцієнт якості діоду;

$k$ - постійна Больцмана;

$q_{e}$ - елементарний заряд;

$T$ - абсолютна температура ФЕП;

$R_{S}$ - внутрішній послідовний опір сонячного елемента;

$R_{p}$ - шунтуючий опір ФЕП. чином [2]:

При застосуванні дводіодної еквівалентної схеми світлова ВАХ ФЕП записується наступним

$$
I=I_{L}-I_{S 1} \cdot\left[e^{\frac{q_{e}\left(U+I R_{S}\right)}{A_{1} k T}}-1\right]-I_{S 2} \cdot\left[e^{\frac{q_{e}\left(U+I R_{S}\right)}{A_{2} k T}}-1\right]-\frac{U+I R_{S}}{R_{p}}
$$

де $I_{s 1}-$ струм насичення першого діоду, що відповідає дифузійному механізму перенесення носіїв заряду;

$I_{s 2}$ - струм насичення другого діоду, що обумовлений рекомбінаційними процесами в p-n переході;

$A_{1}$ - коефіцієнт якості першого діоду;

$A_{2}$ - коефіцієнт якості другого діоду.

Дводіодна еквівалентна схема дозволяє більш точно описати реальну ВАХ ФЕП, втім, потребує знання струмів насичення та коефіцієнтів якості окремо для кожного з двох діодів, роздільне визначення яких є можливим з вимірювання та аналізу темнової ВАХ ФЕП $[4,5]$.

Дещо простіше виглядає ситуація у випадку застосування рівняння ВАX, записаного у відповідності до однодіодної моделі. Для повного опису ВАХ ФЕП в цьому випадку необхідно задати лише п'ять параметрів, а саме: фотострум, струм насичення діоду, його коефіцієнт якості, послідовний та шунтуючий опори. Знаючи ці параметри, а також вказавши температуру, отримуємо трансцендентне рівняння, розв'язання якого в актуальному діапазоні напруг дозволяе побудувати ВАХ як залежність струму ФЕП від його напруги. Незважаючи на меншу кількість параметрів, що описують світлову ВАХ, застосування однодіодної моделі дозволяє отримувати результати з достатньою для практичного використання точністю [6].

Для побудови ВАХ ФЕП можна скористатися стандартними математичними підходами до розв'язання трансцендентних рівнянь, що передбачені в сучасних засобах комп'ютерної математики. Одним з таких потужних засобів, що останнім часом набуває широкого використання для моделювання різноманітних технічних систем, $є$ середовище MATLAB [7]. Завдяки вбудованому пакету Simulink 
програма MATLAB дозволяє здійснювати візуально-орієнтоване блочне імітаційне моделювання динамічних систем, зокрема, різних пристроїв функціональної електроніки, сонячних елементів та фотоелектричних модулів.

Моделювання роботи фотоелектричних панелей в MATLAB/Simulink можна реалізувати за допомогою двох основних блоків [8]: Solar Cell та PV Array. Блок Solar Cell дозволяє моделювати роботу як одиничного ФЕП, так і формувати фотоелектричний модуль з низки послідовно з'єднаних сонячних елементів, кількість яких задається користувачем. На відміну від блоку PV Array, блок Solar Cell надає можливість моделювати ВАХ ФЕП як за однодіодною, так і за дводіодною еквівалентною схемою. Використання паралельно з'єднаних блоків Solar Cell дозволяє створити модель панелі зі змішаним послідовно-паралельним електричним з'єднанням ФЕП.

В якості вхідних даних блок Solar Cell використовує наступні параметри ФЕП: струм короткого замикання та напруга холостого ходу при обраній щільності потоку сонячного випромінювання та температурі, струми насичення діодів, коефіцієнти якості діодів, внутрішній послідовний та шунтуючий опори. Причому в межах однодіодної еквівалентної схеми існує можливість введення вхідних даних в двох конфігураціях, з яких найбільш зручною з точки зору інформації, наявної в технічній документації на модулі, виглядає наступна: безпосередньо задаються такі параметри ФЕП, як струм короткого замикання та напруга холостого ходу при обраній густині потужності світлового потоку та температурі, коефіцієнт якості діоду, послідовний опір. Параметри, яких не вистачає, а саме фотострум і струм насичення діоду, автоматично розраховуються за введеними даними у відповідності до рівняння (1) у припущенні, що шунтуючий опір $R_{p}=\infty$.

В той же час, певні дані, що їх необхідно використовувати в якості вхідних до блоку Solar Cell, відсутні в типовій документації на фотоелектричні панелі [9-11], і виникає потреба в їх визначенні, виходячи $з$ наявної в технічному паспорті інформації. Це, зокрема, такі параметри ФЕП, як коефіцієнт якості діоду та внутрішній послідовний опір.

\section{Формулювання мети дослідження}

Метою роботи є моделювання світлових характеристик серійних зразків фотоелектричних панелей в середовищі MATLAB/Simulink при використанні в якості вхідних даних інформації 3 технічної документації на модулі.

\section{Викладення основного матеріалу дослідження}

Для проведення моделювання обрано три фотоелектричні панелі, а саме: JАР6(BK) 60250/3ВВна основі полікристалічного кремнію виробництва компанії JA Solar Holdings Co., Ltd.[9]; полікристалічна кремнієва панель AS-6P30-270W виробництва Worldwide Energy and Manufacturing USA Co., Ltd. [10]; монокристалічний кремнієвий модуль LG290N1C від компанії LG Electronics U.S.A. Inc.[11].

Моделювання світлових характеристик з наступним їх аналізом для визначенням електричних параметрів сонячних панелей здійснювалось у середовищі MATLAB/Simulink для стандартних умов випробувань (STC) з використанням блочної схеми, що представлена на рис. 1.

Схема складається з блоку Solar Cell, що містить задану кількість послідовно з’єднаних ФЕП у відповідності до технічної документації на модуль. Всі панелі, що досліджувались, складались 360 послідовно з'єднаних ФЕП. Блок констант Rad задає потік сонячної радіації, що надходить на поверхню панелі. Для умов STC щільність потоку сонячної радіації становить 1000 Вт/м² при температурі ФЕП у модулі $25{ }^{\circ} \mathrm{C}$. Електричне навантаження фотоелектричної панелі задається змінним резистором R1, опір якого керується блоком R amp. В якості амперметру та вольтметру використано сенсори струму (A) та напруги (V). Індикацію поточних значень струму, напруги та потужності в електричному колі забезпечують відповідні блоки Display. Побудова світлової BAX та потужностної характеристик панелі реалізована за допомогою блоків IV Graph та PV Graph, відповідно. Аналіз даних щодо струму, напруги та потужності здійснювався засобами Simulation Data Inspector.

Під час моделювання виходили 3 однодіодної еквівалентної схеми ФЕП. Для визначення параметрів блоку Solar Cell, що не зазначені в технічній документації сонячних панелей, а саме, коефіцієнту якості діоду та внутрішнього послідовного опору ФЕП, використовували методику, що базується на аналізі паспортної світлової ВАХ панелі, яка відповідає умовам STC.

Для визначення внутрішнього послідовного опору ФЕП застосовували стандартну методику, яка передбачає аналіз ділянки світлової ВАХ в області напруг, близьких до напруги холостого ходу [12]. Якщо $\left(U_{1 \text { mod }}, I_{1 m o d}\right)$ та $\left(U_{2 m o d}, I_{2 m o d}\right)$ - пара точок на квазілінійній ділянці світлової ВАХ панелі поблизу напруги холостого ходу, то внутрішній послідовний опір модуля становить:

$$
R_{\text {smod }}=\left|\frac{U_{2 \bmod }-U_{1 \mathrm{mod}}}{I_{2 \bmod }-I_{1 \bmod }}\right|
$$




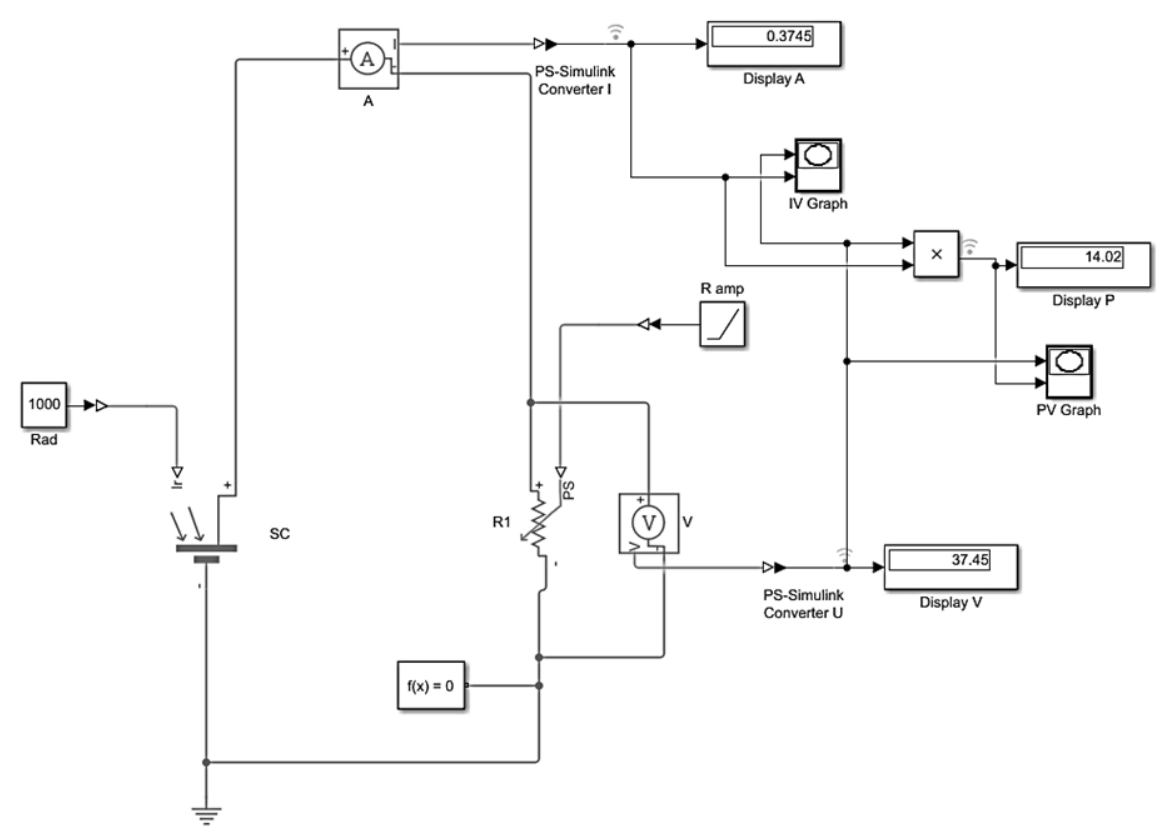

Рис. 1. Візуально-оріснтована блочна схема з побудови світлових характеристик фотоелектричної панелі

Враховуючи послідовну комутацію ФЕП в фотоелектричних панелях, що моделювались, внутрішній послідовний опір окремого ФЕП визначається:

$$
R_{s}=\frac{R_{s \bmod }}{N_{s}}
$$

де $N_{s}$ - кількість послідовно з'єднаних ФЕП в панелі.

Для визначення коефіцієнту якості діоду еквівалентної схеми ФЕП розроблено методику, що базується на аналізі світлової ВАХ панелі поблизу напруги точки максимальної потужності. Якщо $\left(U_{3 m o d}, I_{3 m o d}\right)$ та $\left(U_{4 m o d}, I_{4 m o d}\right)$ - пара точок на світловій ВАХ панелі, то, враховуючи послідовну комутацію ФЕП, напруга і струм окремого сонячного елемента становлять:

$$
U_{3}=\frac{U_{3 m o d}}{N_{s}}, I_{3}=I_{3 m o d} ; \quad U_{4}=\frac{U_{4 m o d}}{N_{s}}, I_{4}=I_{4 m o d}
$$

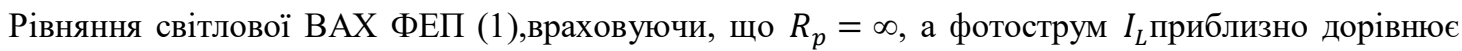
струму короткого замикання $I_{S C}[3]$, запишеться у вигляді:

$$
I=I_{L}-I_{S} \cdot\left[e^{\frac{q_{e}\left(U+I R_{S}\right)}{A k T}}-1\right]
$$

Нехтуючи одиницею в порівнянні зі значенням експоненти, після низки перетворень та логарифмування вираз (6) набуває наступного вигляду:

$$
\ln \left(I_{S C}-I\right)-\ln I_{S}=\frac{q_{e}\left(U+I R_{S}\right)}{A k T} .
$$

Підставляючи в рівняння $(7)$ значення $\left(U_{3}, I_{3}\right)$ та $\left(U_{4}, I_{4}\right)$ отримуємо систему рівнянь:

$$
\left\{\begin{array}{l}
\ln \left(I_{S C}-I_{3}\right)-\ln I_{S}=\frac{q_{e}\left(U_{3}+I_{3} R_{S}\right)}{A k T} \\
\ln \left(I_{S C}-I_{4}\right)-\ln I_{S}=\frac{q_{e}\left(U_{4}+I_{4} R_{S}\right)}{A k T}
\end{array}\right.
$$


Після розв'язання системи рівнянь (8) відносно $A$ маємо наступний вираз для визначення коефіцієнту ідеальності діоду:

$$
A=\frac{q_{e}\left[U_{3}-U_{4}+\left(I_{3}-I_{4}\right) R_{s}\right]}{k T \ln \left(\frac{I_{S C}-I_{3}}{I_{S C}-I_{4}}\right)} .
$$

Отже, маючи в розпорядженні світлову ВАХ з технічної документації на фотоелектричну панель та визначивши попередньо внутрішній послідовний опір ФЕП, за виразом (9) можна розрахувати коефіцієнт якості діоду в еквівалентній схемі і використовувати отримані дані для моделювання роботи панелі в середовищі MATLAB/Simulink.

На рис. 2 представлено світлові ВАХ сонячних панелей, що взяті з технічної документації на відповідні модулі.

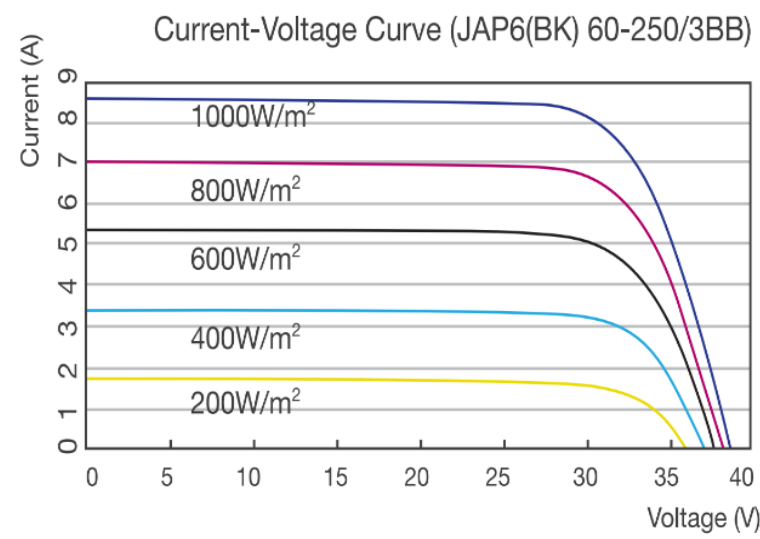

a)

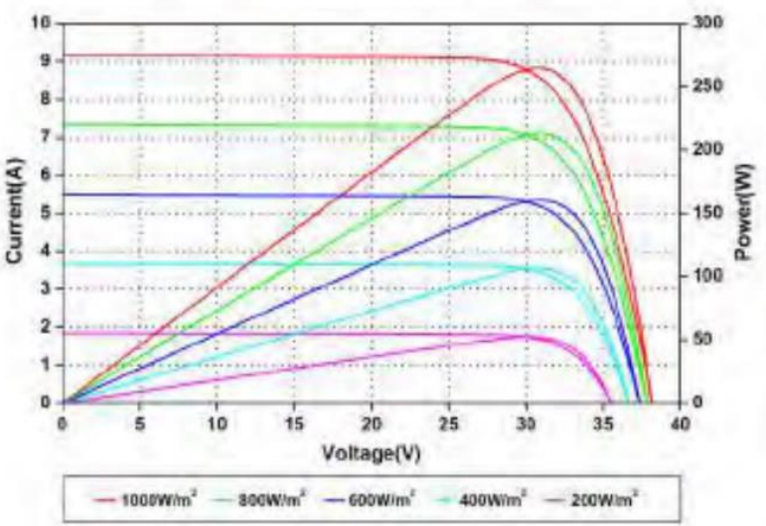

б)

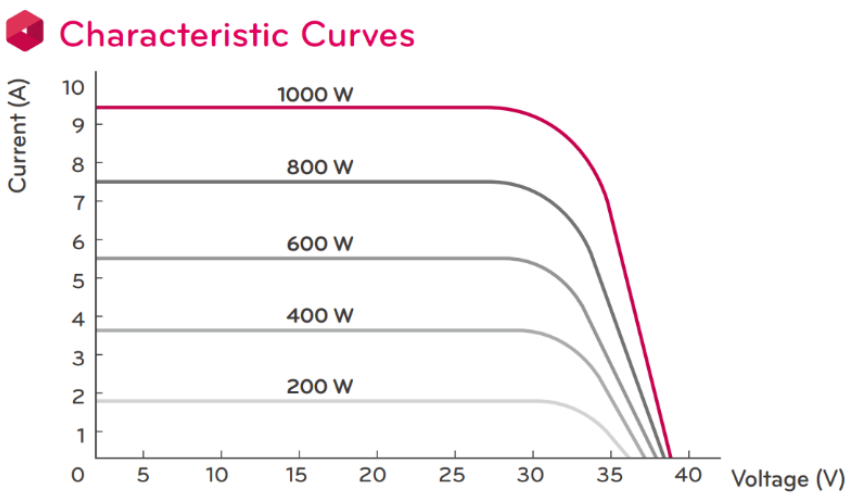

B)

Рис. 2. Світлові ВАХ, наведені в технічній документації на фотоелектричні панелі при температурі $25^{\circ} \mathrm{C}$ та різній щільності потоку сонячного випромінювання: a - JAP6(BK) 60-250/3BB; б - AS-6P30-270W; в - LG290N1C

3 аналізу наведених ВАХ, що відповідають щільності потоку випромінювання 1000 Вт/м², за описаними вище методиками визначено внутрішній послідовний опір ФЕП для кожної 3 панелей та відповідні коефіцієнти якості діоду. Результати розрахунку послідовного опору $R_{s}$ та коефіцієнту якості $A$ представлено в табл. 1 поряд з іншими параметрами ФЕП, такими, як струм короткого замикання $I_{S C}$ та напруга холостого ходу $U_{O C}$, що безпосередньо були взяті 3 технічної документації на відповідні фотоелектричні модулі і використовувались у блоці Solar Cell в якості вхідних даних під час моделювання. 
Параметри ФЕП, прийняті під час моделювання

\begin{tabular}{|l|c|c|c|c|}
\hline \multicolumn{1}{|c|}{ Модуль } & $I_{S C}, \mathrm{~A}$ & $U_{O C}, \mathrm{~B}$ & $R_{s}$, Ом & $A$ \\
\hline JAP6(BK) 60-250/3BB & 8,92 & 0,628 & 0,0065 & 1,110 \\
\hline AS-6P30-270W & 9,09 & 0,640 & 0,0100 & 0,999 \\
\hline LG290N1C & 9,80 & 0,653 & 0,0053 & 1,204 \\
\hline
\end{tabular}

На рис. 3 представлено результати моделювання в середовищі MATLAB/Simulink світлових BAX зазначених фотоелектричних панелей в умовах STC, де по осі абсцис відкладено напругу модуля, B, а по осі ординат - струм, А.

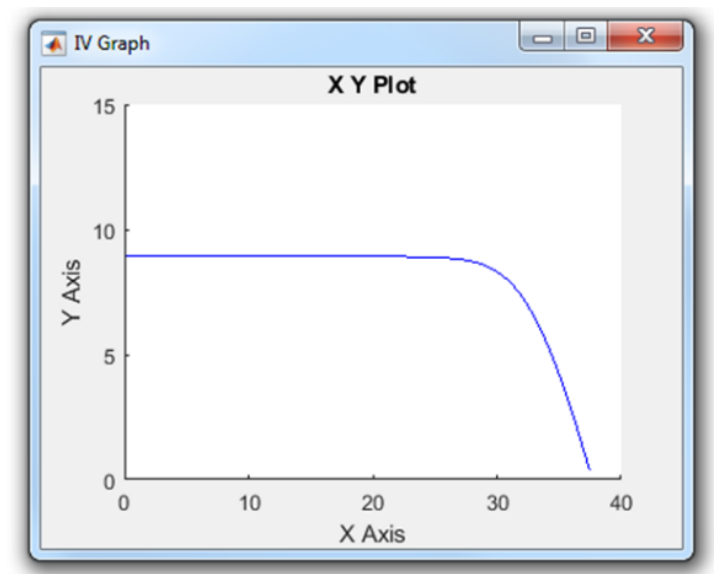

a)

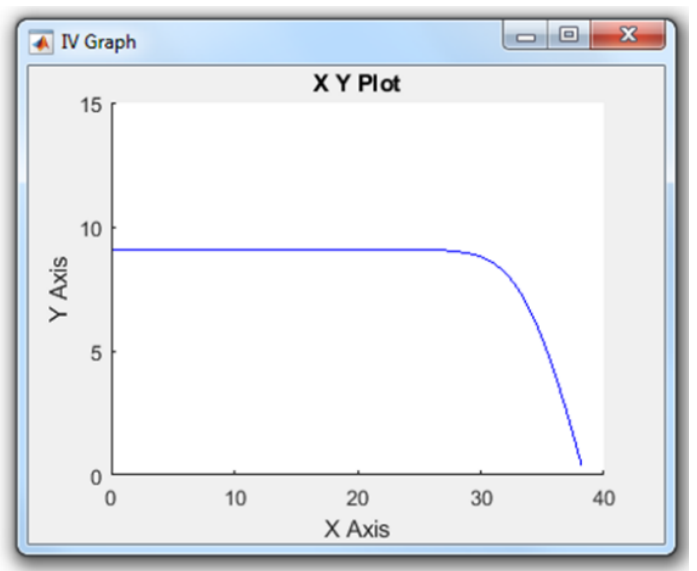

б)

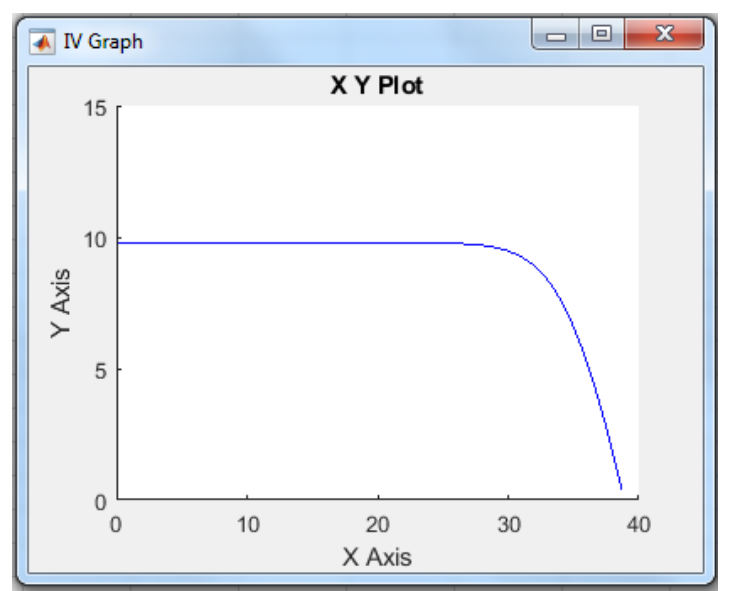

B)

Рис. 3. Результати моделювання світлових ВАX панелей для умов STC: a - JAP6(BK) 60-250/3BB; б - AS-6P30-270W; B - LG290N1C

Аналіз числових даних, що описують отримані світлові ВАХ, засобами Simulation Data Inspector дозволив встановити значення максимальної електричної потужності $P_{m}$ кожної з фотоелектричних панелей, струм $I_{m}$ та напругу $U_{m}$ в точці максимальної потужності, визначити ефективність перетворення сонячного випромінювання $\eta$, а також порівняти отримані результати з даними, наведеними у технічній документації до панелей (табл. 2).

Як показує аналіз табл. 2, для всіх зразків панелей, що досліджувались, розбіжність між результатами моделювання та параметрами 3 технічної документації $є$ меншою за допустиме у виробництві відхилення від паспортних значень у 3\%. Це свідчить про прийнятність застосованого підходу щодо визначення внутрішнього послідовного опору та коефіцієнта якості для ФЕП, що складають фотоелектричну панель, а також про коректність візуально-орієнтованої моделі модуля, що базується на використанні блоку Solar Cell в наближенні однодіодної еквівалентної схеми. 
Таблиця 2

Параметри панелей, що отримані в результаті моделювання, та їх порівняння з даними, наведеними в технічній документації

\begin{tabular}{|c|c|c|c|c|c|c|}
\hline Параметр & $I_{S C}, \mathrm{~A}$ & $U_{O C}, \mathrm{~B}$ & $P_{m}, \mathrm{BT}$ & $I_{m}, \mathrm{~A}$ & $U_{m}, \mathrm{~B}$ & $\eta, \%$ \\
\hline \multicolumn{7}{|c|}{ Панель JАР6(ВК) 60-250/3ВВ } \\
\hline Моделювання & 8,92 & 37,45 & 249,43 & 8,39 & 29,73 & 15,25 \\
\hline Паспортне значення & 8,92 & 37,66 & 250 & 8,35 & 29,94 & 15,29 \\
\hline $\begin{array}{l}\text { Відносне } \quad \text { відхилення } \\
\text { паспортних значень, \% }\end{array}$ & - & 0,56 & 0,23 & 0,48 & 0,70 & 0,26 \\
\hline \multicolumn{7}{|c|}{ Панель AS-6P30-270W } \\
\hline Моделювання & 9,09 & 38,35 & 264,97 & 8,60 & 30,81 & 16,29 \\
\hline Паспортне значення & 9,09 & 38,4 & 270 & 8,69 & 31,1 & 16,6 \\
\hline $\begin{array}{l}\text { Відносне } \quad \text { відхилення } \\
\text { паспортних значень, \% }\end{array}$ & - & 0,13 & 1,86 & 1,03 & 0,93 & 1,87 \\
\hline \multicolumn{7}{|c|}{ Панель LG290N1C } \\
\hline Моделювання & 9,8 & 39,18 & 287,96 & 9,20 & 31,30 & 17,56 \\
\hline Паспортне значення & 9,8 & 39,2 & 290 & 9,19 & 31,8 & 17,7 \\
\hline $\begin{array}{l}\text { Відносне відхилення } \\
\text { паспортних значень, \% }\end{array}$ & - & 0,05 & 0,70 & 0,11 & 1,57 & 0,79 \\
\hline
\end{tabular}

\section{Висновки}

В середовищі MATLAB/Simulink створено візуально-орієнтовану модель фотоелектричної панелі, що базується на використанні блоку Solar Cell в наближенні однодіодної еквівалентної схеми ФЕП.

Для проведення моделювання запропоновано використовувати в якості вхідних даних інформацію, наведену в технічній документації до панелей, та розроблено методику визначення параметрів еквівалентної схеми ФЕП, що їх не зазначено в документації, а саме, внутрішнього послідовного опору та коефіцієнту якості діоду.

Зі світлових ВАХ, наведених в технічному паспорті, у відповідності до розробленої методики визначено внутрішній послідовний опір та коефіцієнт якості діоду для ФЕП панелей ЈАР6(BК) 60250/3BB, AS-6P30-270W та LG290N1C, що дозволило у середовищі MATLAB/Simulink побудувати світлові BAX зазначених панелей для умов STC. Порівняння параметрів панелей, визначених 3 аналізу змодельованих світлових ВАХ, з даними, наведеними у технічній документації, засвідчило коректність запропонованого підходу до моделювання роботи реальних фотоелектричних модулів у MATLAB/Simulink.

\section{Список використаної літератури}

1. Андронова О.В. Оптимізація розміщення приймачів сонячної енергії рядами для кліматичних умов півдня України / О.В. Андронова, В.В. Курак // Відновлювана енергетика. - 2020. - №2 - С. $45-53$. DOI:https://doi.org/10.36296/1819-8058.2020.2(61).45-53

2. Фолькер К. Системы возобновляемых источников энергии / К. Фолькер. - Астана: Фолиант, 2013. $-432 \mathrm{c}$.

3. Курак В.В. Експериментальне визначення потоку сонячного випромінювання із застосуванням паспортних параметрів модуля фотоелектричних перетворювачів/ В.В. Курак, О.В. Андронова // Вісник ХНТУ. - 2021. - №1(76). - C. 35-42. DOI:https://doi.org/10.35546/kntu2078-4481.2021.1.4

4. Macabebe Erees Q.B. Parameter extraction from dark current-voltage characteristics of solarcells. Erees Q.B. Macabebe, E. ErnestvanDyk // South African Journal of Science. - 2008. - Vol. 104, N 9. - P. 401404.

5. Measurements and analysis of the dark I-V-T characteristics of a photovoltaic cell: KX0B22-12X1F / D. Bonkoungou[et al] // Proc. 8th IEET International Conference on Smart Grid. - 2020. - P. 157-162.DOI: https://doi.org/10.1109/icSmartGrid49881.2020.9144904

6. Зиновьев В.В. Математическая модель фотоэлектрического преобразователя с использованием W-функции Ламберта / В. В. Зиновьев, А. П. Бельтюков, О. А. Бартенев //Известия Института математики и информатики УдГУ. - 2016. - №2(48). - С. 22-30.

7. Дьяконов В.П. МАTLAB. Полный самоучитель / В.П. Дьяконов. - М.: ДМК Пресс, 2012. -768 c.

8. Simscape Block Libraries [Електронний pecypc] / MathWorks [Сайт]. - Режим доступу: https://www.mathworks.com/help/physmod/simscape/ug/introducing-the-simscape-block-libraries.html(дата звернення: 20.07.21). - Назва з екрану.

9. Технические данные панели Ja Solar JАР6(ВК) 60/240-260/3ВВ [Электронный ресурс] / 
АксиомПлюс [Сайт]. - Режим доступа: https://axiomplus.com.ua/solnechnyie-paneli/product-75901/(дата обращения: 2.11.20). - Название с экрана.

10. Технический паспорт Amerisolar AS-6P30-265W [Электронный ресурс] / АксиомПлюс [Сайт]. - Режим доступа: https://axiomplus.com.ua/solnechnyie-paneli/product-74667/(дата обращения: 20.07.21). Название с экрана.

11. LG290N1C-G3. Product Specifications [Electronic resource]. - Режим доступа: https://eclass.duth.gr/modules/document/file.php/TMC384/2019-2020/MonoX-Neon-LG290N1C-G320140915.pdf/(дата обращения: 4.11.20). - Название с экрана. $280 \mathrm{c}$.

12. Колтун М.М. Оптика и метрология солнечных элементов / М.М. Колтун. - М.: Наука, 1985. -

\section{References}

1. Andronova O.V. Optymizatsiya rozmishchennya pryymachiv sonyachnoyi enerhiyi ryadamy dlya klimatychnykh umov pivdnya Ukrayiny / O.V. Andronova, V.V. Kurak // Vidnovlyuvana enerhetyka. 2020. pp. 45-53. DOI:https://doi.org/10.36296/1819-8058.2020.2(61).45-53

2. Folker K. Systemy vozobnovlyaemykh ystochnykov énerhyy / K. Folker. - Astana: Folyant, 2013. $432 \mathrm{p}$.

3. Kurak V.V. Eksperymentalne vyznachennya potoku sonyachnoho vyprominyuvannya iz zastosuvannyam pasportnykh parametriv modulya fotoelektrychnykh peretvoryuvachiv/ V.V. Kurak, O.V. Andronova // Visnyk KHNTU. 2021. №1(76). pp. 35-42. DOI:https://doi.org/10.35546/kntu2078-4481.2021.1.4

4. Macabebe Erees Q.B. Parameter extraction from dark current-voltage characteristics of solarcells. Erees Q.B. Macabebe, E. ErnestvanDyk // South African Journal of Science. 2008. Vol. 104, N 9. Pp. 401-404.

5. Measurements and analysis of the dark I-V-T characteristics of a photovoltaic cell: KX0B22-12X1F / D. Bonkoungou [et al] // Proc. 8th IEET International Conference on Smart Grid. 2020. P. 157-162. DOI: https://doi.org/10.1109/icSmartGrid49881.2020.9144904

6. Zynovev V.V. Matematycheskaya model fotoélektrycheskoho preobrazovatelya s yspolzovanyem Wfunktsyy Lamberta / V. V. Zynovev, A. P. Beltyukov, O. A. Bartenev //Yzvestyya Ynstytuta matematyky y ynformatyky UdHU. 2016. №2(48). pp. 22-30.

7. Dyakonov V.P. MATLAB. Polnyy samouchytel / V.P. Dyakonov. Moscow DMK Press, 2012. 768 p.

8. Simscape Block Libraries [Elektronnyy resurs] / MathWorks [Sayt]. - Rezhym dostupu: https://www.mathworks.com/help/physmod/simscape/ug/introducing-the-simscape-block-libraries.html(data zvernennya: 20.07.21). - Nazva z ekranu.

9. Tekhnycheskye dannye panely Ja Solar JAP6(VK) 60/240-260/3BB [Élektronnyy resurs] / AksyomPlyus [Sayt]. - Rezhym dostupa: https://axiomplus.com.ua/solnechnyie-paneli/product-75901/(data obrashchenyya: 2.11.20). - Nazvanye s ékrana.

10. Tekhnycheskyy pasport Amerisolar AS-6P30-265W [Élektronnyy resurs] / AksyomPlyus [Sayt]. Rezhym dostupa: https://axiomplus.com.ua/solnechnyie-paneli/product-74667/(data obrashchenyya: 20.07.21). Nazvanye s ékrana.

11. LG290N1C-G3. Product Specifications [Electronicresource]. - Rezhym dostupa: https://eclass.duth.gr/modules/document/file.php/TMC384/2019-2020/MonoX-Neon-LG290N1C-G320140915.pdf/(data obrashchenyya: 4.11.20). - Nazvanye s ékrana. 1985. $280 \mathrm{p}$.

12. Koltun M.M. Optyka y metrolohyya solnechnykh élementov / M.M. Koltun. Moscow. Nauka, 